\title{
Severe Asthma Questionnaire: translation to Portuguese and cross-cultural adaptation for its use in Portugal
}

\author{
Questionário de Asma Grave: tradução para Português \\ e adaptação transcultural para o seu uso em Portugal
}

Data de receção / Received in: 30/04/2019 Data de aceitação / Accepted for publication in: 07/06/2019

\footnotetext{
Rev Port Imunoalergologia 20I9;27 (3):233-242
}

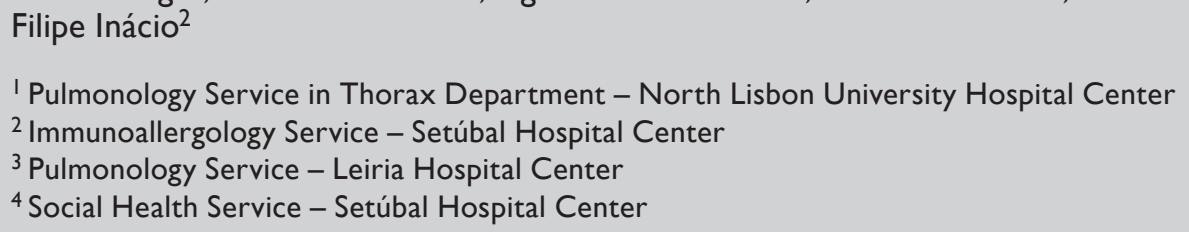

\section{ABSTRACT}

Objective: To translate and perform a cross-cultural adaptation of the Severe Asthma Questionnaire (SAQ) so that it can be used as a tool to measure the impact of asthma symptoms on quality of life as well as the impact of asthma treatments in severe asthmatic patients in Portugal. Methods: Based on the principles of good practice for the translation and cross-cultural adaptation of such instruments, the protocol included the following steps: acquisition of authorization from the authors of the original questionnaire; translation of the instrument to Portuguese, carried out by two health professionals; reconciliation; back-translation to English, carried out by two health professionals who are fluent in Portuguese; review of the back-translation; harmonization; review and approval of the questionnaire; focus groups involving 12 patients who completed and improved the wording of the questionnaire; analysis of the results; and review and preparation of the final version of the instrument approved by the original SAQ team. Results: The final version of the SAQ for use in Portugal included minor modifications suggested by the patients. The mean and standard deviations of the patients age was $50.08 \pm 13.43$ years and $50 \%$ were female. All had some level of education and the majority (58.3\%) had a favourable economic background. Conclusions: The SAQ demonstrated to be comprehensible, clear, and appropriate. The original questionnaire and the 
Vera Clérigo, Bárbara Cardoso, Lígia Sofia Fernandes, Christine Costa, Otília Garcia, Elza Tomaz, Filipe Inácio

translated version, cross-culturally adapted for use in Portugal, were reliably comparable. Consequently, it can become an extensively used tool for severe asthma patients.

Keywords: Severe asthma, questionnaires, translations.

\section{RESUMO}

Objetivo: Traduzir e realizar uma adaptação transcultural do Questionário de Asma Grave (SAQ, do inglês Severe Asthma Questionnaire) para que possa ser usado como ferramenta para medir o impacto dos sintomas de asma na qualidade de vida e o impacto do tratamento da asma nos doentes com asma grave em Portugal. Métodos: Com base nos princípios de boas práticas para a tradução e adaptação transcultural de tais instrumentos, o protocolo incluiu as seguintes etapas: aquisição de autorização dos autores do questionário original, tradução do instrumento para português, realizada por dois profissionais de saúde, reconciliação, retrotradução para inglês, realizada por dois profissionais de saúde fluentes em português, revisão da retrotradução, harmonização, revisão e aprovação do questionário, grupos de discussão envolvendo 12 doentes que completaram e melhoraram a redação do questionário; análise dos resultados e revisão e preparação da versão final do instrumento aprovada pela equipa original do SAQ. Resultados: A versão final do SAQ para uso em Portugal incluiu pequenas modificações sugeridas pelos doentes. A média e desvio-padrão da idade dos doentes foi de 50,08 \pm 13,43 anos e $50 \%$ eram do sexo feminino. Todos apresentavam algum nível de escolaridade e a maioria $(58,3 \%)$ possuía um histórico económico favorável. Conclusões: O SAQ demonstrou ser compreensível, claro e apropriado. O questionário original e a versão traduzida, adaptada culturalmente para uso em Portugal, eram comparáveis de forma confiável. Consequentemente, pode representar uma ferramenta amplamente utilizada para doentes com asma grave.

Palavras-chave: Asma grave, questionários, traduções.

\section{INTRODUCTION}

$\mathrm{T}$ he existing asthma specific health related quality of life (HRQoL) scales are not optimally aimed for severe asthmatic patients', since their quality of life is considerably different from that of patients with mild to moderate disease. Contributing factors are the larger burden of symptoms, higher risk of exacerbations and treatment particularities. To fill this gap the Severe Asthma Questionnaire (SAQ) was designed so that items can measure the impact of symptoms and treatments on quality of life of severe asthmatics patients. It goes along with FDA recommendations ${ }^{2}$ that outcome measures should be created for particular populations in order to ensure content validity.

The SAQ development process started by identifying the additional deficits experienced by severe asthmatic patients comparing to those with mild or moderate asthma. Based on the gathered information a questionnaire was created. Then, patient focus groups evaluated the 
questionnaire and recommended amendments to word$\mathrm{ing}^{3}$, in order to the SAQ could be optimised. The final quantitative validating data was provided by Michael $\mathrm{E}$ Hyland et al. ${ }^{4}$ Finally comparison with other HRQoL scales concerning the sensitivity to change was performed.

The SAQ combines two parts along four pages. The first part includes a 16 items questionnaire to measure the disease burden over the last two weeks in 16 different and relevant domains to severe asthmatic patients. Patients respond to each item by rating how difficult their disease makes that life domain on a 7-point scale averaged to produce a total domain score (1-16). The second part includes three global quality of life scales, one to assess global quality of life during the last two weeks and the remaining two to assess global quality of life during the worst and best months of the year. These scales are based on the Global Quality of Life Questionnaire (GQoL) that is written in a Borg scale format. Only the first is used to obtain a global quality of life score $(0-100)$. The two others, not yet validated, may be used in clinical evaluation or in clinical trials as a method to detect response shifts. Preliminary data indicates a minimal clinically important difference (MCID) of 0.46 for the SAQ score and 6.0 for the SAQ global 5 .

For clinical use the questionnaire validation for the target population is mandatory. Therefore, the objective of the present study was to translate and perform a cross-cultural adaptation of the SAQ so that it can be used as a tool to measure the impact of asthma symptoms on quality of life and the impact of asthma treatments in severe asthmatic patients in Portugal.

\section{METHODS}

The present study was approved by the Research Ethics Committee of Setúbal Hospital Center, located in the city of Setúbal, Portugal. Before completing the questionnaire, all patients gave written informed consent.

Two bilingual speakers translated the SAQ into Portuguese, and two other bilingual speakers back translated.
The translated and back translated versions were discussed and a final version agreed. The following step was qualitative seeking for discrepancies in understanding between the Portuguese version and the original one. All the steps of the process follow the methodology indicated by the authors and GA(2)LEN recommendations for assessing patient-reported outcomes and health-related quality of life in clinical trials on allergy ${ }^{6}$ :

I. Preparation: The Plymouth SAQ team ${ }^{5}$ was initially contacted and approved the license for the use of the questionnaire.

2. Translation: The translation from the source language (English) into the target language (Portuguese) was performed by two health professionals familiar with severe asthma and with health-related quality of life terminology. The health professionals had knowledge of the English-speaking culture but their primary language was that of the target culture (i.e. bilingual). They translated the questionnaire independently and pursued to translate it conceptually instead of literally.

3. Reconciliation: The two bilingual health professionals reviewed and compared the two translations and agreed on a consensus version. Any problematic items were discussed. Any inadequate words, expressions, concepts and discrepancies between the forward translation and the SAQ were identified, discussed and resolved. The result of this process was an agreed forward translation.

4. Back-translation to English: The forward translation was translated back into English by two independent bilingual health professionals also familiar with severe asthma. Neither had access to the SAQ original version, and were instructed to execute a literal translation.

5. Harmonization: The original SAQ and the two backward translations were reviewed for consistency. Any discrepancies were discussed and resolved with the bilingual health professionals who undertook 
the forward translation and a satisfactory translated version was achieved.

6. Focus groups: The objective of this step was to determine the understandability and acceptability of the translated questionnaire in the target population, by improving the wording of the questionnaire and using the patients as partners in the translation process. According to the original protocol ${ }^{7}$, there should be a minimum of two focus groups each comprising six to eight patients. Patients were eligible to participate in the focus group step of the protocol if they reflected the population under consideration i.e., patient with severe asthma according to GINA guidelines ${ }^{8}$, a balance of males and females, economic background and ages. Patients were excluded if they refused to participate, were unable to read, sign, or understand the informed consent form. Selection of patients was purposive, with the aim of achieving a reasonable spread of patients on these criteria. In this step of the protocol the above requirements were respected. The invitation to participate in the study was done in a similar way to every patient. Twelve patients suffering from severe asthma were divided into two focus groups and the meetings were conducted by a moderator with extensive experience of qualitative interviews. Six of selected patients were followed at the Immunoallergology Service in Setúbal Hospital Center and six at the Pulmonology Service, Thorax Department - North Lisbon Hospital Center. The Portuguese version of the SAQ was presented to both groups separately being the patients asked to read and complete the questionnaire. Then the moderator took each question and discussed the individual interpretations, noting any disagreements in the group and suggestions. Participants were allowed to write a comment on the interpretation and clarity for each item. Since the recommendations from both groups were similar, no further research was needed, and a final word- ing of the questionnaire was reached. The comments from patients led to the introduction of some minor modifications to the questionnaire.

7. Analysis of the results of the focus groups and conclusion: Patient interpretation and suggestions were analysed and the Portuguese version of the questionnaire was modified accordingly, since the meaning was not compromised. All analyses were performed using statistical package of social sciences (SPSS) version 20.0. (SPSS Inc, Chigago IL, USA). The distribution of continuous variables was expressed as mean and standard deviation.

8. Review: The review step consisted of a final evaluation of the translated questionnaire, which was carefully reviewed by the four health professionals and the moderator and discussed with an expert. The objective was to perform a final evaluation of the translation and correct any misspellings or grammatical errors.

9. Final report: A final report was presented to the Plymouth SAQ team in order to document the process of translation and cross-cultural adaptation of the SAQ, so the final version of the questionnaire could be validated for use in Portugal.

The final version was written according to the $\mathrm{New}$ Portuguese Spelling Reform. The present article originated from that document.

\section{RESULTS}

Participant patients were literate and were Portuguese native speakers, being 6 males and 6 females, aged 31 to 74 years, mean age being $59.08 \pm 13.43$ years (Table I). In the focus group step of the protocol, the two focus group reunions took place in the Immunoallergology Service - Setúbal Hospital Center and Pulmonology Service - North Lisbon Hospital Center, and lasted 60 to $90 \mathrm{~min}$. 
Table I. Characterization of patients

\begin{tabular}{|l|c|}
\hline \multicolumn{1}{|c|}{ Characteristic } & N (\%) \\
\hline Age, years \pm SD (range) & $59.08 \pm$ I3.43 (3।-74) \\
\hline Gender & $6(50.0)$ \\
Male & $6(50.0)$ \\
Female & \\
\hline Education level & $5(41.7)$ \\
Elementary school & $4(33.3)$ \\
High school & $3(25.0)$ \\
College University & \\
\hline Economic background* & $5(41.7)$ \\
Desfavorable & $7(58.3)$ \\
Beneficial & \\
\hline
\end{tabular}

* Relates to a combination of an individual's and family's income and occupation. Patients with a desfavorable economic background (eg. low income or unemployed) had been evaluated by the Social Health Service in Setúbal Hospital Center or North Lisbon University Hospital Center.

The patients completed and reviewed the questionnaire and provided verbal feedback on each sentence, item and response option. All patients completed all evaluation items. The total domain score and the global quality of life score for each patient are presented on Table 2. The correlation coefficient $(r)$ between the two groups of values was 0,82 .

Most of the participants suggested the addition of some words on the first and final pages of the SAQ to clarify the fields to be filled. None of the patients wrote any comments on the interpretation and clarity of the questions, this constituting evidence that the questions were deemed clear by the patients. Alternative wording used by the participants, comments and proposals were noted and later discussed with the experts to determine whether the questionnaire required changes. Questionnaire items were refined accordingly.

Only minor modifications were required. In the review step of the protocol, a consensus was reached that it would be clearer for patients that the expressions "nas páginas seguintes" e "à direita" were added to the introductory sentence of the first and the last pages, respec-
Table 2. SAQ results of the patients

\begin{tabular}{|c|c|c|}
\hline Patients & $\begin{array}{c}\text { Total Domain } \\
\text { Score }\end{array}$ & $\begin{array}{c}\text { Global Quality } \\
\text { of Life Score }\end{array}$ \\
\hline 1 & 4,56 & 40 \\
\hline 2 & 5,50 & 80 \\
\hline 3 & 3,80 & 40 \\
\hline 4 & 3,47 & 45 \\
\hline 5 & 6,67 & 95 \\
\hline 6 & 5,93 & 95 \\
\hline 7 & 4,13 & 70 \\
\hline 8 & 6,47 & 70 \\
\hline 9 & 5,07 & 40 \\
\hline 10 & 2,13 & 35 \\
\hline 11 & 6,13 & 90 \\
\hline 12 & 2,20 & 30 \\
\hline Mean & 4,67 & 60,83 \\
\hline
\end{tabular}

tively, turning easier to the patients to fill the questionnaire.

The final version of the SAQ for use in Portugal incorporated all of the aforementioned modifications and resulted in a four-page document reported in Figure I.

\section{DISCUSSION}

Considering that the variety of new therapeutic options makes possible a personalised treatment in severe asthma ${ }^{9,10}$, a reliable tool is needed to evaluate the impact of asthma symptoms and treatments on these patients. To fulfil the purpose, the SAQ was developed and validated being currently used worldwide and has been also translated in Italy ${ }^{4}$.

Analysis of the SAQ obtained data can provide physicians a set of predictive parameters serving as a valuable guide for therapeutic decisions. 
Vera Clérigo, Bárbara Cardoso, Lígia Sofia Fernandes, Christine Costa, Otília Garcia, Elza Tomaz, Filipe Inácio

QAG

Data:

Nome:

Questionário de Asma Grave (QAG)

SAQ

Severe Asthma

Questionnaire

(Quality of Life)

Este questionário mede a qualidade de vida de pessoas com asma grave.

Por favor, indique nas páginas seguintes o quanto a asma torna a sua vida difícil usando a seguinte escala de respostas:

1 = muito, muito difícil (o pior possível)

$2=$ muito difícil

$3=$ difícil

4 = moderadamente difícil

5 = pouco difícil

6 = ligeiramente difícil (pouco percetível)

$7=$ sem problema

Por favor, tenha em consideração os seus sintomas de asma, e quaisquer efeitos secundários da medicação que toma por causa da asma grave.

SAQ 2017

(C) 2017 University of Plymouth and Plymouth Hospitals NHS Trust. All Rights Reserved.

Contact: mhyland@plymouth.ac.uk. This questionnaire may be used without charge for

noncommercial purposes being made available und er the creative commons licence:

Attribution-NonCommercial-NoDerivatives 4.0 International (CC BY-NC-ND 4.0)

Página 1 de 4

Vire a página

Figure I. Severe Asthma Questionnaire translation to Portuguese 
QAG

Faça um círculo à volta do número que melhor descreve a sua situação:

Durante as últimas duas semanas, quão difícil tem sido esta parte da sua vida por causa dos seus sintomas de asma e dos efeitos secundários da medicação que toma?
Muito, muito
Sem
difícil
problema

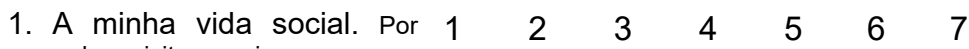

exemplo: visitar amigos, passear

com amigos, conversar com amigos,

ir a bares ou restaurantes, e festas.

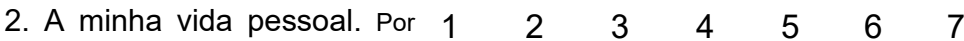
exemplo: lavar-me, vestir-me, cuidar de mim, a minha vida afetiva.

3. As minhas atividades de $1 \quad 2 \begin{array}{lllllll}2 & 3 & 4 & 5 & 6 & 7\end{array}$ lazer. Por exemplo: caminhar por prazer, fazer atividade física e desportiva, viajar, ir de férias.

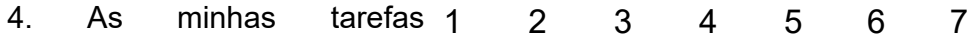
domésticas. Por exemplo: trabalho doméstico, fazer as compras de supermercado, manter a casa em ordem, jardinagem.

5. O meu trabalho ou escola. Por exemplo: faltar ao trabalho ou escola, não ser capaz de fazer tudo

$\begin{array}{llllll}2 & 3 & 4 & 5 & 6 & 7\end{array}$

o que quero.

6. A minha vida familiar (l $\begin{array}{lllllllll}0 & 1 & 2 & 3 & 4 & 5 & 6 & 7\end{array}$ quanto a asma me afeta). Por

exemplo: cuidar das crianças,

encarar as responsabilidades

familiares.

7. A minha vida familiar (o quanto a minha asma afeta os outros). Por exemplo: os outros faltarem ao trabalho por minha causa, cuidarem das crianças na minha vez, desconforto em membros da minha família por causa da minha saúde.

\begin{tabular}{lllllll}
1 & 2 & 3 & 4 & 5 & 6 & 7 \\
\hline & & & & & &
\end{tabular}

Página 2 de $4 \quad$ Vire a página

Figure I. Severe Asthma Questionnaire translation to Portuguese (continuation) 
QAG

Muito, muito

Sem

difícil

problema

8. Depressão. Por exemplo: $\quad \begin{array}{llllllll}1 & 2 & 3 & 4 & 5 & 6 & 7\end{array}$

sentindo-se triste, insatisfeito, farto.

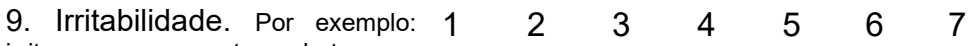

irritar-me com os outros, chatear-me

com os outros mais do que 0

deveria.

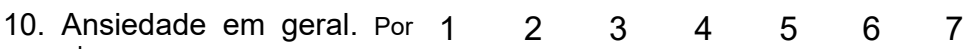

exemplo: preocupar-se com as

coisas, estar sempre nervoso.

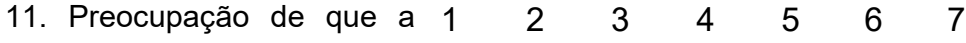

asma possa agravar. Por

exemplo: os medicamentos

deixarem de ajudar, ter crises mais

frequentes.

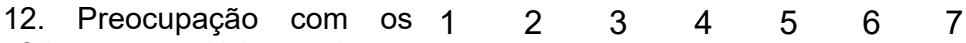

efeitos secundários a longo

prazo da medicação. Por

exemplo, a preocupação de que a

medicação cause cataratas, diabetes

ou fraturas dos ossos.

13. Ficar cansado(a). $\begin{array}{lllllllll}\text { Por } & 1 & 2 & 3 & 4 & 5 & 6 & 7\end{array}$

exemplo: sentir-se cansado(a) sem

razão aparente, acordar de manhã

a sentir-se cansado(a).

14. Problemas à noite. Por $11 \quad 2 \quad \begin{array}{llllll}3 & 4 & 5 & 6 & 7\end{array}$ exemplo: dificuldade em

adormecer, despertar facilmente,

acordar frequentemente.

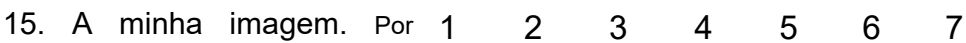

exemplo: o meu peso, a minha pele

fica com nódoas negras facilmente,

usar medicação em público, o que

os outros pensam de mim.

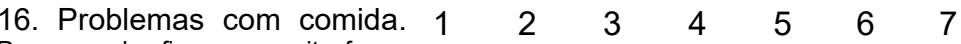

Por exemplo: fico com muita fome,

não consigo parar de comer

problemas de estômago (dor, gases,

etc.).

Página 3 de 4

Vire a página

Figure I. Severe Asthma Questionnaire translation to Portuguese (continuation) 
QAG - Escala Global

Utilize a escala à esquerda desta página para classificar à direita a sua qualidade de vida GLOBAL, devido aos seus SINTOMAS DE ASMA e aos EFEITOS SECUNDÁRIOS da sua medicação.

100 Qualidade de vida perfeita

95 Qualidade de vida quase perfeita

90

85 Qualidade de vida muito boa

80

75

70 Qualidade de vida boa

65

60

Qualidade de vida moderadamente boa 55

50

45

40 Qualidade de vida aceitável 35

30

Qualidade de vida má

25

20

15 Qualidade de vida muito má

10

5 Qualidade de vida extremamente má

0 Sem qualidade de vida

\section{Durante as últimas DUAS}

\section{SEMANAS}

a minha qualidade de vida tem sido

\begin{tabular}{|c|}
\hline $\begin{array}{l}\text { 2. Durante o mês do ano em que a minha } \\
\text { asma está no seu MELHOR, } \\
\text { a minha qualidade de vida tem sido }\end{array}$ \\
\hline escreva um número \\
\hline
\end{tabular}

3. Durante o mês do ano em que a minha asma está no seu PIOR,

a minha qualidade de vida tem sido

escreva um número

Página 4 de 4

Figure I. Severe Asthma Questionnaire translation to Portuguese (continuation) 
In the present study, the SAQ was translated to Portuguese and adapted for use in Portugal. The cross-culturally adaptation process of an existing questionnaire is faster, cheaper and more efficient than developing a new instrument. In addition, the local and international data can be compared. With the available Portuguese version of SAQ, future clinical studies conducted in the country can be easily compared with similar studies conducted in other countries.

The cross-cultural adaptation process is complex and involves more than just a simple translation". The principles of good practice for translation and cross-cultural adaptation of such instruments were guaranteed and the methodology employed was based on established guidelines. Patients were chosen considering the diversity in gender, age, education level and economical background demanded by the protocol. Their results in SAQ showed a strong correlation between the total domain score and the global quality of life score, reflecting consistency of responses and concordance between the scores. We followed all of the procedures required to achieve a semantic, experimental and conceptual equivalence between the original questionnaire and the translated version. We also sought to preserve the psychometric properties.

The Portuguese version of the SAQ proved to be easy to understand, clear, applicable and fully adapted to the local culture, being consistently equivalent to the original version. It can be useful in public health care facilities and private clinics, as well as contribute to clinical research in severe asthma.

The Portuguese version of the SAQ and guidance for scoring can be downloaded, free of charge for research purposes, from the website of the questionnaire ${ }^{5}$.

\section{Conflicts of interest}

The authors have no conflicts of interest to declare.

\section{Acknowledgement}

We would like to thank the Plymouth SAQ team, who developed and validated the SAQ, for their kindness and for allowing us to translate the questionnaire to Portuguese and adapt it for use in Portugal.

The authors wish to acknowledge all who assisted and participated in the study, namely study subjects who willingly participated in the study and the Pulmonology and Immunoallergology Hospital staff and the Pulmonologist Dr. Dolores Moniz, who assisted in coordinating the patients.

\section{REFERENCES}

I. Hyland ME, Whalley B, Jones RC, Masoli M. A qualitative study of the impact of severe asthma and its treatment showing that treatment burden is neglected in existing asthma assessment scales. Quality of Life Research 2015;24:631-9.

2. Patient-Reported Outcome Measures: Use in Medical Product Development to Support Labeling Claims. 2009. Available online at: https://www.fda.gov/media/77832/download

3. Hyland ME, Lanario JW, Pooler J, Masoli M, Jones RC. How patient participation was used to develop a questionnaire that is fit for purpose for assessing quality of life in severe asthma. Health and quality of life outcomes. 2018;16:24.

4. Hyland ME, Jones RC, Lanario JW, Masoli M. The construction and validation of the Severe Asthma Questionnaire. Eur Respir J 2018;52:1800618.

5. Severe Asthma Questionnaire - Access the Questionnaire. Available online at: http://www.saq.org.uk/download.aspx.

6. Baiardini I, Bousquet PJ, Brzoza Z, Canonica GW, Compalati E, Fiocchi A, et al. Global Allergy and Asthma European Network. Recommendations for assessing patient-reported outcomes and health-related quality of life in clinical trials on allergy: a GA(2) LEN taskforce position paper. Allergy 2010;65:290-5.

7. Severe Asthma Questionnaire - Translation Protocol. Available online at: http://www.saq.org.uk/Download/TranslationProtocol.pdf.

8. Global Initiative for Asthma GINA Report: Global Strategy for Asthma Management and Prevention. 2018. Available online at: https://ginasthma.org/gina-reports/

9. Samitas K, Delimpoura V, Zervas E, Gaga M. Anti-IgE treatment, airway inflammation and remodelling in severe allergic asthma: current knowledge and future perspectives. Eur Respir Rev 2015; 24:594-60I.

10. Delimpoura V, Bostantzoglou C, Liu N, Nenna R. Novel therapies for severe asthma in children and adults. Breathe 2018; 14:59-62.

II. Koller M, West K. Linguistic Validation Manual for Patient-Reported Outcomes (PRO) Instruments, By C. Acquadro, K. Conway, C. Girourdet \& I. Mear, MAPI ResearchTrust, Lyon, France, 2004, I84 pp, ISBN: 2-952202I-0-9. Qual Life Res. 2005; I4:179I- 2. 